\title{
Effect of light colour on forced hyacinth
}

\section{Malgorzata Śmigielska, Marek Jerzy}

\author{
Department of Ornamental Plants \\ Faculty of Horticulture, Poznań University of Life Sciences \\ Dąbrowskiego 159, 60-594 Poznań, Poland \\ e-mail: ozdobne4@up.poznan.pl
}

\begin{abstract}
Three cultivars of Hyacinthus orientalis L. were forced under artificial light using fluorescent lamps emitting white, blue, green, yellow and red light. Quantum irradiance was determined as 12.5 and $25 \mu \mathrm{mol} \mathrm{m}^{-2} \mathrm{~s}^{-1}$. Day length was 12 and six hours, respectively. Daily light integral was $0.54 \mathrm{~mol} \mathrm{~m}^{-2}$. A significant effect of light colour on flowering date and plant quality was observed. Plants forced in blue and red light were the first to flower. Plants exposed to red light formed longer inflorescences. Plants forced under lamps emitting blue light formed shorter, more rigid flower shoots with shorter leaves.

There were no significant differences between plants grown under $25 \mu \mathrm{mol} \mathrm{m} \mathrm{m}^{-2}$ of quantum irradiance for six hours per day and plants grown under light with a quantum irradiance of $12.5 \mu \mathrm{mol} \mathrm{m}^{-2} \mathrm{~s}^{-1}$ for 12 hours per day. This means that the light-dosing variant did not exert any effect on the growth and flowering of hyacinths.
\end{abstract}

Key words: Hyacinthus orientalis L., fluorescent lighting, growing room, quantum irradiance, day length, cultivars

\section{INTRODUCTION}

The increasing costs of greenhouse utilisation have induced plant producers and scientists to search for new technological solutions permitting the forcing of bulbous ornamental plants in loci of another type equipped with artificial light sources, built of wood and bricks, where obtaining an adequately high temperature is easier and cheaper. Such a system is offered by a "closed plant production system".

The effect of light colour on the growth and flowering of bulbous ornamental plants forced in the period of winter is still not well recognised. Results have been published from studies on the effect of light quality exerted on the flowering of tulips and narcissuses (Bach et al. 1997, 1998; Woźny and Jerzy 2004 a, 2004 b; Jerzy et al. 2005). Red light accelerated the flowering of the abovementioned plants, while blue light retarded their flowering. Blue light improved the rigidity of stems and leaves and it contributed to a better colour of the plants. On the other hand, red light caused the elongation of stems and flowers, but at the same time, it deteriorated the rigidity of stems and leaves.

Piszczek et al. (1996) and Woźny and Jerzy (2007) showed that narcissuses bloom the earliest with daylight, while red light delays their flowering by several days and blue light postpones flowering even by one week. In blue light, narcissuses produce shorter and more rigid flower shoots.

The present study discusses the results of an experiment investigating the effect of light colour exerted on hyacinths forced in a growing room from bulbs cooled at a temperature of $+9^{\circ} \mathrm{C}$.

\section{MATERIAL AND METHODS}

The cooling of Hyacinthus orientalis L. bulbs at a temperature of $+9^{\circ} \mathrm{C}$ began on 15 October 2007 . Bulbs of $19-20 \mathrm{~cm}$ had been planted earlier into flowerpots with $11 \mathrm{~cm}$ diameters in a substrate consisting of a mixture of peat and sand (2:0.5). 
After 12 weeks, the pots with the bulbs were transferred to a growth room, and on 10 January 2008, the forcing of plants was begun. The plants were placed under fluorescent lamps (Philips TLD) with 36 W power: white colour $33(370-700 \mathrm{~nm})$, blue colour 18 (400-580 nm), green colour 17 (360$630 \mathrm{~nm})$, yellow colour $16(500-650 \mathrm{~nm})$ and red colour 15 (600-700 nm).

Two variants of daily light dose were introduced. In the first variant, light of $12.5 \mu \mathrm{mol} \mathrm{m}^{-2} \mathrm{~s}^{-1}$ quantum irradiance was applied for 12 hours per 24 hour period. In the second variant, light of $25 \mu \mathrm{mol} \mathrm{m}^{-2} \mathrm{~s}^{-1}$ was applied for six hours per day and night period. In each variant, the daily light dose amounted to $0.54 \mathrm{~mol} \mathrm{~m}^{-2}$. One combination comprising the daily light dose and the light colour consisted of 10 plants. A replication was represented by one plant.

Air temperature was maintained at a level of 16$18^{\circ} \mathrm{C}$, while the relative air humidity was $60-70 \%$.

The beginning of flowering was determined by the date of the appearance of the first flower in the lower part of the inflorescence, which indicated the plant's readiness for harvest. On that date, the plant height was measured from the place where it grew out from the bulb, the length of the inflorescence alone and the length of the longest leaf.

The results were statistically elaborated by the method of analysis of variance for a two-factorial experiment and the significance of differences was estimated by the Duncan test at $\mathrm{p}=0.05$.

Table 1. Forcing period (days) of three hyacinth cultivars depending on light colour of different fluorescent lamps and daily light dose

\begin{tabular}{|c|c|c|c|c|c|c|c|}
\hline \multirow{2}{*}{\multicolumn{2}{|c|}{$\begin{array}{l}\text { Daily light dose } \\
\text { (variants) }\end{array}$}} & \multicolumn{5}{|c|}{ Light colour } & \multirow{2}{*}{$\begin{array}{c}\text { Means for daily } \\
\text { light dose }\end{array}$} \\
\hline & & white & blue & green & yellow & red & \\
\hline \multicolumn{8}{|c|}{ 'Anna Marie' } \\
\hline I & $25 \mu \mathrm{mol} \mathrm{m} \mathrm{m}^{-2} \mathrm{~s}^{-1} \times 6 \mathrm{~h}$ & 13.1 & 12.9 & 13.4 & 13.3 & 12.9 & $13.1 \mathrm{~A}$ \\
\hline II & $12.5 \mu \mathrm{mol} \mathrm{m}^{-2} \mathrm{~s}^{-1} \times 12 \mathrm{~h}$ & 13.1 & 12.7 & 13.2 & 13.2 & 11.8 & $12.8 \mathrm{~A}$ \\
\hline & s for light colour & $13.1 \mathrm{~b}$ & $12.8 \mathrm{ab}$ & $13.3 \mathrm{~b}$ & $13.2 \mathrm{~b}$ & $12.3 \mathrm{a}$ & \\
\hline \multicolumn{8}{|c|}{ 'Fondant' } \\
\hline I & $25 \mu \mathrm{mol} \mathrm{m}{ }^{-2} \mathrm{~s}^{-1} \times 6 \mathrm{~h}$ & 13.7 & 12.9 & 13.9 & 13.7 & 12.8 & $13.4 \mathrm{~A}$ \\
\hline II & $12.5 \mu \mathrm{mol} \mathrm{m}^{-2} \mathrm{~s}^{-1} \times 12 \mathrm{~h}$ & 12.3 & 12.0 & 13.8 & 13.7 & 12.1 & $12.8 \mathrm{~A}$ \\
\hline & is for light colour & $13.0 \mathrm{~b}$ & $12.4 \mathrm{a}$ & $13.8 \mathrm{~b}$ & $13.7 \mathrm{~b}$ & $12.4 \mathrm{a}$ & \\
\hline \multicolumn{8}{|c|}{ 'White Pearl' } \\
\hline I & $25 \mu \mathrm{mol} \mathrm{m} \mathrm{m}^{-2} \mathrm{~s}^{-1} \times 6 \mathrm{~h}$ & 12.0 & 11.8 & 12.2 & 12.6 & 11.9 & $12.1 \mathrm{~A}$ \\
\hline II & $12.5 \mu \mathrm{mol} \mathrm{m}^{-2} \mathrm{~s}^{-1} \times 12 \mathrm{~h}$ & 12.1 & 12.1 & 12.6 & 12.8 & 11.7 & $12.3 \mathrm{~A}$ \\
\hline & s for light colour & $12.0 \mathrm{a}$ & $11.9 \mathrm{a}$ & $12.4 \mathrm{~b}$ & $12.7 \mathrm{~b}$ & $11.8 \mathrm{a}$ & \\
\hline
\end{tabular}

Table 2. Height of plant $(\mathrm{cm})$ of three hyacinth cultivars depending on light colour of different fluorescent lamps and daily light dose

\begin{tabular}{|c|c|c|c|c|c|c|c|}
\hline \multirow{2}{*}{\multicolumn{2}{|c|}{$\begin{array}{l}\text { Daily light dose } \\
\text { (variants) }\end{array}$}} & \multicolumn{5}{|c|}{ Light colour } & \multirow{2}{*}{$\begin{array}{l}\text { Means for daily } \\
\text { light dose }\end{array}$} \\
\hline & & white & blue & green & yellow & red & \\
\hline \multicolumn{8}{|c|}{ 'Anna Marie' } \\
\hline I & $25 \mu \mathrm{mol} \mathrm{m} \mathrm{m}^{-2} \mathrm{~s}^{-1} \times 6 \mathrm{~h}$ & $27.0 \mathrm{bc}$ & $24.6 \mathrm{a}$ & $27.4 \mathrm{c}$ & $25.0 \mathrm{ab}$ & $25.9 \mathrm{ab}$ & $26.0 \mathrm{~A}$ \\
\hline II & $12.5 \mu \mathrm{mol} \mathrm{m}^{-2} \mathrm{~s}^{-1} \times 12 \mathrm{~h}$ & $25.9 \mathrm{ab}$ & $26.2 \mathrm{ab}$ & $26.8 \mathrm{bc}$ & $26.2 \mathrm{ab}$ & $26.9 \mathrm{bc}$ & $26.4 \mathrm{~A}$ \\
\hline & s for light colour & $26.4 \mathrm{ab}$ & $25.4 \mathrm{a}$ & $27.1 \mathrm{~b}$ & $25.6 \mathrm{a}$ & $26.4 \mathrm{ab}$ & \\
\hline \multicolumn{8}{|c|}{ 'Fondant' } \\
\hline I & $25 \mu \mathrm{mol} \mathrm{m} \mathrm{s}^{-2} \times 6 \mathrm{~h}$ & $20.8 \mathrm{~b}$ & $19.3 \mathrm{ab}$ & $19.8 \mathrm{ab}$ & $21.3 \mathrm{~b}$ & $19.4 \mathrm{ab}$ & $20.1 \mathrm{~A}$ \\
\hline II & $12.5 \mu \mathrm{mol} \mathrm{m}^{-2} \mathrm{~s}^{-1} \times 12 \mathrm{~h}$ & $20.1 \mathrm{~b}$ & $19.8 \mathrm{ab}$ & $20.8 \mathrm{~b}$ & $24.2 \mathrm{c}$ & $20.6 \mathrm{~b}$ & $21.1 \mathrm{~A}$ \\
\hline & is for light colour & $20.4 \mathrm{ab}$ & $19.6 \mathrm{a}$ & $20.3 \mathrm{ab}$ & $22.8 \mathrm{c}$ & $20.0 \mathrm{ab}$ & \\
\hline \multicolumn{8}{|c|}{ 'White Pearl' } \\
\hline I & $25 \mu \mathrm{mol} \mathrm{m} \mathrm{m}^{-2} \mathrm{~s}^{-1} \times 6 \mathrm{~h}$ & $24.1 \mathrm{bc}$ & $23.9 \mathrm{c}$ & $24.8 \mathrm{bc}$ & $23.6 \mathrm{bc}$ & $25.9 \mathrm{c}$ & $24.9 \mathrm{~A}$ \\
\hline II & $12.5 \mu \mathrm{mol} \mathrm{m}{ }^{-2} \mathrm{~s}^{-1} \times 12 \mathrm{~h}$ & $22.8 \mathrm{ab}$ & $22.4 \mathrm{ab}$ & $24.6 \mathrm{bc}$ & $23.7 \mathrm{bc}$ & $25.9 \mathrm{c}$ & $23.5 \mathrm{~A}$ \\
\hline & s for light colour & $23.4 \mathrm{ab}$ & $23.1 \mathrm{a}$ & $24.7 \mathrm{~b}$ & $23.6 \mathrm{ab}$ & $25.9 \mathrm{c}$ & \\
\hline
\end{tabular}


Table 3. Length of inflorescence (cm) of three hyacinth cultivars depending on light colour of different fluorescent lamps and daily light dose

\begin{tabular}{|c|c|c|c|c|c|c|c|}
\hline \multirow{2}{*}{\multicolumn{2}{|c|}{$\begin{array}{l}\text { Daily light dose } \\
\text { (variants) }\end{array}$}} & \multicolumn{5}{|c|}{ Light colour } & \multirow{2}{*}{$\begin{array}{l}\text { Means for daily } \\
\text { light dose }\end{array}$} \\
\hline & & white & blue & green & yellow & red & \\
\hline \multicolumn{8}{|c|}{ 'Anna Marie' } \\
\hline I & $25 \mu \mathrm{mol} \mathrm{m} \mathrm{m}^{-2} \mathrm{~s}^{-1} \times 6 \mathrm{~h}$ & $9.6 \mathrm{abc}$ & $9.2 \mathrm{abc}$ & $9.7 \mathrm{~cd}$ & $9.6 \mathrm{bc}$ & $10.1 \mathrm{de}$ & $9.6 \mathrm{~A}$ \\
\hline II & $12.5 \mu \mathrm{mol} \mathrm{m}{ }^{-2} \mathrm{~s}^{-1} \times 12 \mathrm{~h}$ & $9.3 \mathrm{abc}$ & $9.4 \mathrm{abc}$ & $9.4 \mathrm{abc}$ & $10.3 \mathrm{de}$ & $10.8 \mathrm{e}$ & $9.8 \mathrm{~A}$ \\
\hline & s for light colour & $9.4 \mathrm{bc}$ & $9.3 \mathrm{bc}$ & $9.5 \mathrm{bc}$ & $9.9 \mathrm{~cd}$ & $10.4 \mathrm{~d}$ & \\
\hline \multicolumn{8}{|c|}{ 'Fondant' } \\
\hline I & $25 \mu \mathrm{mol} \mathrm{m} \mathrm{m}^{-2} \mathrm{~s}^{-1} \times 6 \mathrm{~h}$ & $8.4 \mathrm{abc}$ & $8.6 \mathrm{abc}$ & $8.0 \mathrm{a}$ & $9.3 \mathrm{~cd}$ & $9.5 \mathrm{abc}$ & $8.8 \mathrm{~A}$ \\
\hline II & $12.5 \mu \mathrm{mol} \mathrm{m}^{-2} \mathrm{~s}^{-1} \times 12 \mathrm{~h}$ & $8.4 \mathrm{abc}$ & $9.0 \mathrm{bc}$ & $8.3 \mathrm{ab}$ & $8.3 \mathrm{ab}$ & $9.1 \mathrm{bc}$ & $8.6 \mathrm{~A}$ \\
\hline & is for light colour & $8.4 \mathrm{a}$ & $8.8 \mathrm{~b}$ & $8.1 \mathrm{a}$ & $8.8 \mathrm{~b}$ & $9.3 \mathrm{c}$ & \\
\hline \multicolumn{8}{|c|}{ 'White Pearl' } \\
\hline I & $25 \mu \mathrm{mol} \mathrm{m} \mathrm{m}^{-2} \mathrm{~s}^{-1} \times 6 \mathrm{~h}$ & $14.3 \mathrm{ab}$ & $14.7 \mathrm{abc}$ & $14.4 \mathrm{abc}$ & $13.8 \mathrm{ab}$ & $16.0 \mathrm{c}$ & $14.6 \mathrm{~A}$ \\
\hline II & $12.5 \mu \mathrm{mol} \mathrm{m}{ }^{-2} \mathrm{~s}^{-1} \times 12 \mathrm{~h}$ & $13.1 \mathrm{a}$ & $13.9 \mathrm{ab}$ & $13.7 \mathrm{ab}$ & $13.3 \mathrm{ab}$ & $15.0 \mathrm{bc}$ & $13.8 \mathrm{~A}$ \\
\hline & is for light colour & $13.7 \mathrm{a}$ & $14.3 \mathrm{a}$ & $14.0 \mathrm{a}$ & $13.5 \mathrm{a}$ & $15.5 \mathrm{~b}$ & \\
\hline
\end{tabular}

Table 4. Length of the longest leaf $(\mathrm{cm})$ of three hyacinth cultivars depending on light colour of different fluorescent lamps and daily light dose

\begin{tabular}{llccccc}
\hline \multirow{2}{*}{$\begin{array}{l}\text { Daily light dose } \\
\text { (variants) }\end{array}$} & \multicolumn{5}{c}{ Light colour } & Means for daily \\
light dose
\end{tabular}

\section{RESULTS}

All plants began flowering in the third ten days of January. The period of forcing was the shortest under lamps with blue and red light for all hyacinths. The 'White Pearl' cultivar also flowered earlier under lamps with white light (Tab. 1). No difference was found between the length of the forcing period of plants grown under light of $25 \mu \mathrm{mol} \mathrm{m} \mathrm{m}^{-2} \mathrm{~s}^{-1}$ irradiance for six hours per day (variant 1) and the length of the forcing period of plants grown under light of $12.5 \mu \mathrm{mol} \mathrm{m}^{-2} \mathrm{~s}^{-1}$ irradiance for 12 hours per day (variant 2).

Plants grown under lamps with blue light were shortest, but their height was not always significantly different than the height of plants grown under different colour lights (Tab. 2). The highest were the plants grown under green light ('Anna Marie'), yellow light ('Fondant') or red light ('White Pearl').

No other significant difference was found between the height of plants forced under lights with a quantum irradiance of $25 \mu \mathrm{mol} \mathrm{m} \mathrm{m}^{-2} \mathrm{~s}^{-1}$ for six hours per day (variant 1) and the height of plants grown under lights with an irradiance of $12.5 \mu \mathrm{mol}$ $\mathrm{m}^{-2} \mathrm{~s}^{-1}$ for 12 hours per day (variant 2).

We observed the exertion of a significantinfluence of light colour on the length of inflorescence in all three hyacinth cultivars (Tab. 3). Under red light, the inflorescences were the longest. Under white, blue and green light, the hyacinths produced shorter and less flabby inflorescences. 
No significant difference was found between the length of inflorescence in plants grown under lights with a quantum irradiance of $25 \mu \mathrm{mol} \mathrm{m} \mathrm{m}^{-2} \mathrm{~s}^{-1}$ for six hours per day (variant 1) and the length of inflorescence in plants grown under lights with an irradiance of $12.5 \mu \mathrm{mol} \mathrm{m}^{-2} \mathrm{~s}^{-1}$ for 12 hours per day (variant 2).

The length of the longest leaf of the 'Fondant' cultivar did not depend on the light colour. The 'Anna Marie' and 'White Pearl' cultivars produced short leaves under the influence of blue light (Tab. 4).

No significant difference was found between the length of the longest leaf in plants grown under lights with a quantum irradiance of $25 \mu \mathrm{mol} \mathrm{m} \mathrm{m}^{-2} \mathrm{~s}^{-1}$ for six hours per day (variant 1) and the length of the longest leaf in plants grown under lights with an irradiance of $12.5 \mu \mathrm{mol} \mathrm{m}^{-2} \mathrm{~s}^{-1}$ for 12 hours per day (variant 2).

\section{DISCUSSION}

Plant growth and development can be controlled using natural or synthetic growth regulators. However, because of the risk of an unfavourable and even toxic effect of these substances for both people and the environment, the use of some chemical substances including some growth retardants is prohibited in many countries. For several years, studies have been carried out which aim at the utilisation of different light colours for controlling the growth and flowering of plants (Tonecki 1998). Tulips, narcissuses, crocuses, hyacinths, but also small bulbous plants can be forced using artificial light sources in storerooms and warehouses (Piróg 1995). Tulips forced by the standard method are satisfied with a light intensity of $250 \mathrm{~lx}$ and a day length of six hours. On the other hand, tulips forced by a special method bloom earlier with light intensity increased to the level of $1000 \mathrm{~lx}$ (Jerzy 1980). The present knowledge about the possibility of forcing hyacinths not in the greenhouse but only by artificial light is not great (Śmigielska and Jerzy 2009). Our own studies indicate that using fluorescent lamps emitting blue light, one can obtain flowering hyacinths of good quality. For this purpose, one can apply a six-hour day and quantum irradiance of $25 \mu \mathrm{mol} \mathrm{m} \mathrm{m}^{-2} \mathrm{~s}^{-1}$ or a 12-hour day and quantum irradiance of $12.5 \mu \mathrm{mol} \mathrm{m} \mathrm{m}^{-2} \mathrm{~s}^{-1}$.

The quoted values are lower than the values of $5000 \mathrm{~mW} \mathrm{~m}^{-2}\left(23 \mu \mathrm{mol} \mathrm{m}^{-2} \mathrm{~s}^{-1}\right)$ used for 12 hours per day applied by Templing and Verbruggen (1977), but our values are sufficient for hyacinths forced in the period from December to February.
The values used by the above-mentioned authors correspond to a daily light dose of $0.99 \mathrm{~mol}$ $\mathrm{m}^{-2}$, while in our experiment the dose was $0.54 \mathrm{~mol}$ $\mathrm{m}^{-2}-$ almost half. At the same time, there was no significant difference between plants grown under lights with a quantum irradiance of $25 \mu \mathrm{mol} \mathrm{m} \mathrm{m}^{-2} \mathrm{~s}^{-1}$ for six hours per day and plants grown under light with a quantum irradiance of $12.5 \mu \mathrm{mol} \mathrm{m} \mathrm{m}^{-2} \mathrm{~s}^{-1}$ for 12 hours per day, which means that the variant of light dosing did not exert any effect on the growth and flowering of hyacinths.

An exact understanding of the influence of artificial light on the growth and flowering of plants permits a possible shortening of the production cycle, saving the costs of electric energy and thereby increasing the profitability of the winter production of hyacinths without a greenhouse.

Our own studies indicate that the period of hyacinth forcing was the shortest under fluorescent lamps emitting light with blue and red colours. Under the blue colour lamps, the plants were slightly shorter and also had shorter leaves.

The inflorescences were the longest under red colour lamps. According to the opinion of Kopcewicz et al. (1992), red light stimulates the production of gibberellins, which exert an effect on the elongation growth of shoots, also including the inflorescence. The effect of red light exerted on the shoots of hyacinths in the culture in vitro was also observed by Bach and Pawłowska (1996).

\section{CONCLUSIONS}

The experiments carried out so far indicate that the flowering date and quality of forced hyacinths depend on the light colour.

1. The period of forcing was the shortest under fluorescent lamps emitting blue and red colour light.

2. Plants forced under blue light formed shorter, more rigid flower shoots with shorter leaves.

3. Plants exposed to red light formed longer inflorescences with flabby flower shoots.

\section{REFERENCES}

Bach A., PawŁowska B., 1996. Effect of light quality on growth and development of bulbous plants in long term cultures. Seventh Intern. Symp. On Flower Bulbs, 10-16 March, Herzliya, Izrael, Abstract: 94.

Bach A., WŁodarczyk Z., Świderski A., 1997. Wpływ rodzaju światła na wzrost i rozwój tulipanów pędzonych w szklarniach. Zesz. Probl. Post. Nauk Roln. 449: 23-30. 
Bach A., WŁodarczyk Z., Świderski A., 1998. Wpływ rodzaju doświetlania na wzrost i rozwój tulipanów pędzonych bez dostępu światła naturalnego. Ogólnopol. Konf. „Ogrodnictwo ozdobne przełomu wieków”, 14-15 maj, Kraków: 27.

JERZY M., 1980. Artificial light as a substitute for daylight in forcing of tulips. Acta Hort. 109: 105-110.

Jerzy M., Piszczer P., Woźny A., 2005. Wpływ barwy światła na zimowe kwitnienie narcyzów pędzonych metoda $+5^{\circ}$ C. Zesz. Probl. Post. Nauk Roln. 504: 111-118.

Kopcewicz J., Tretyn A., Cymerski M., 1992. Fitochrom i morfogeneza roślin. PWN, Warszawa.

PIróG J., 1995. Lampy stosowane w pędzeniu roślin cebulowych. Konf. „Pędzenie Ozdobnych Roślin Cebulowych", 16 luty, Poznań: 71-73.

Piszczek P., Jerzy M., Zalewska M., 1996. Wzrost i kwitnienie narcyzów w warunkach naturalnego i sztucznego oświetlenia. Zesz. Nauk. ATR w Bydgoszczy, Rolnictwo 39: 25-32.

Śmigielska M., Jerzy M., 2009. Post-harvest life of hyacinths forced by different colours of artificial light. Acta Sci. Pol., Hort. Cult. 8(4): 3-10.

Templing B.C., Verbruggen M.A., 1977. Lighting Technology in Horticulture. N.V. Philips' Gloeilampenfabrieken, Eindhoven: 32-47.

Tonecki J., 1998. Wykorzystanie systemu fitochromowego do sterowania procesami wzrostu i kwitnienia roślin. Ogólnopol. Konf. „Ogrodnictwo ozdobne przełomu wieków”, 14-15 maj, Kraków: 92.

WoŹNY A., JERZY M., 2004 a. Wpływ barwy światła na jakość tulipanów pędzonych metodą $+5 \mathrm{C}$. Acta Sci. Pol., Hort. Cult. 3(2): 3-11.

WoźNY A., JERZY M., 2004 b. Wpływ barwy światła na zimowe kwitnienie tulipana. Pr. Komis. Nauk Rol. i Biol. BTN, Seria B, Nr 52: 375-381.
WoźNy A., JERZY M., 2007. Effect of light wavelength on growth and flowering of narcissi forced under shortday and low quantum irradiance conditions. J. Hort. Sci. \& Biotechnol. 82(6): 924-928.

\section{PĘDZENIE HIACYNTÓW PRZY ŚWIETLE O RÓŻNEJ BARWIE}

Streszczenie: Cebule trzech odmian hiacyntów pędzono przy sztucznym świetle, pod lampami fluorescencyjnymi typu TLD-36 W, emitującymi światło białe, niebieskie, zielone, żółte i czerwone. Wprowadzono dwa warianty dobowej ilości światła: w pierwszym światło o natężeniu napromienienia kwantowego $12,5 \mu \mathrm{mol} \mathrm{m} \mathrm{m}^{-2} \mathrm{~s}^{-1}$ stosowano przez 12 godzin na dobę, w drugim światło o natężeniu napromienienia kwantowego $25 \mu \mathrm{mol} \mathrm{m}^{-2} \mathrm{~s}^{-1}$ stosowano przez 6 godzin na dobę, co w każdym wariancie odpowiadało dobowej ilości światła wynoszącej $0,54 \mathrm{~mol} \mathrm{~m}^{-2}$. Wariant dozowania dobowej ilości światła nie wywarł wpływu ani na termin kwitnienia roślin ani na ich jakość.

Stwierdzono istotny wpływ barwy światła na wzrost i kwitnienie hiacyntów. Pod lampami o barwie niebieskiej i czerwonej hiacynty zakwitały najwcześniej. Rośliny pędzone pod lampami o świetle czerwonym tworzyły dłuższe kwiatostany i były bardziej wiotkie. Rośliny pędzone pod światłem niebieskim były nieco niższe od pozostałych i miały krótsze liście.

Received June 28, 2010; accepted September 21, 2011 